\title{
Tubular Necrosis, Acid-Base and Electrolyte Abnormalities Associated with Gasoline Vapour-induced Nephrotoxicity
}

\author{
Christopher Edet Ekpenyong ${ }^{1 \star}$, Daniel Emmanuel Otokpa ${ }^{2}$ \\ ${ }^{1}$ Department of Physiology (Cardio-renal unit), Faculty of Basic Medical \\ Sciences, University of Uyo, Uyo, Nigeria \\ ${ }^{2}$ Department of Medicine (Renal Unit) University of Calabar Teaching \\ Hospital Calabar, Nigeria
}

\author{
*Corresponding author \\ Christopher Edet Ekpenyong, Department of Physiology, Faculty of Basic \\ Medical Sciences, University of Uyo, Uyo, Nigeria
}

Submitted: 19 Aug 2020; Accepted: 22 Aug 2020; Published:08 Sept 2020

\begin{abstract}
Introduction: This study aimed to assess the effect of exposure to gasoline vapor $(G V)$ on the histomorphology and biochemical markers of renal function in rats.

Methods: Twenty-four mature Wistar Albino rats weighing 180-200 $\mathrm{g}$ were randomly divided into two groups ( $n=12$ per group). Animals in group 1 (G1) served as unexposed controls, while animals in group 2 (G2) were exposed to GV for 35 days. At the end of the exposure, the animals were sacrificed, and blood samples were collected for biochemical analysis while the kidneys were removed and processed for histopathological evaluation.

Results: Serum biochemical markers of renal function in the exposed group differed significantly $(p<0.05)$ from the unexposed group in urea $(45.16 \pm 1.00 \mathrm{mg} / \mathrm{dl}$ versus(vs) $13.20 \pm 0.69 \mathrm{mg} / \mathrm{dl})$, creatinine $(1.16 \pm 0.27 \mathrm{mg} / \mathrm{dl} \mathrm{vs} 0.38 \pm$ $0.10 \mathrm{mg} / \mathrm{dl})$, uric acid $(3.66 \pm 0.82 \mathrm{mmol} / \mathrm{L}$ vs $1.96 \pm 0.08 \mathrm{mmol} / \mathrm{L})$, potassium $(6.90 \pm 0.27 \mathrm{mmol} / \mathrm{L} \mathrm{vs} 3.57 \pm 0.26 \mathrm{mmol} / \mathrm{L})$, sodium $(182.60 \pm 3.21 \mathrm{mmol} / \mathrm{L}$ vs $141.33 \pm 10.46 \mathrm{mmol} / \mathrm{L})$, chloride $(119.00 \pm 1.58 \mathrm{mmol} / \mathrm{L} \mathrm{vs} 103.33 \pm 2.07 \mathrm{mmol} / \mathrm{L}), \mathrm{pH}$ (6.82 \pm 0.22 vs $7.38 \pm 0.25)$, bicarbonate $(16.60 \pm 5.03 \mathrm{mmol} / \mathrm{L} v \mathrm{~s} 26.50 \pm 3.45 \mathrm{mmol} / \mathrm{L})$, and glucose $(125.60 \pm 16.23 \mathrm{mg} /$ $d l$ vs $83.33 \pm 4.46 \mathrm{mg} / \mathrm{dl}$ ). Histopathological examination of kidney sections revealed areas of degenerative and necrotic changes in the glomerulus, tubules, and renal vasculature, particularly in the cortical portion of the kidney. Conclusion: Chronic exposure to gasoline compounds may be associated with significant structural and biochemical derangements in kidney function.
\end{abstract}

Keywords: Hydrocarbon, Nephrotoxicity, Metabolic Acidosis, Hyperkalemia, Histopathological Changes

\section{Introduction}

The rising incidence of kidney disease has become a global public health burden particularly in developing countries, including subSaharan Africa [1]. Kidney disease also contributes to the rising incidence of cardiovasculardisease and stroke[2]. Globally, approximately 3 million people have different forms/stages of chronic kidney disease and a significant number of them are undiagnosed, and therefore are untreated [3]. Numerous epidemiological studies have reported high prevalence rates $(8-45 \%)$ of kidney disease in Nigeria [4-8].

Several factors are implicated in the etiology of kidney disease including socio-cultural, genetic, and environmental factors [810]. From an environmental perspective, it is known that exposure to environmental nephrotoxic pollutants/solvents is common and increasing, which is contributing to the rising incidence of kidney diseases, particularly among those who are in occupations that exposed them to these nephrotoxic solvents. For instance, in
European countries, approximately 10 million workers are exposed to solvents, and in the United States of America, approximately 4 million workers are exposed to chemicals, some of which are suspected to have nephrotoxic effects (based on data from animal studies), likewise in Canada, where volatile organic compounds (VOC) are used in many workplaces, and several millions of workers within Canada are exposed daily [11-13].

Individuals can be exposed to worksites during the dispensing, transportation, storage, or application of a particular chemical. Exposure to nephrotoxic chemicals can occur through dermal contact, inhalation, or ingestion of contaminated water or foods. However, inhalation is the most common route of human exposure. Acute inhalation exposure to solvents was shown to cause kidney damage several hundred years ago [12]. The high susceptibility of the kidney to chemical injury can be explained by its high blood flow (about $25 \%$ of cardiac output); high metabolic activity; sensitivity to vasoactive compounds; very large endothelial surface by weight; numerous transporters, leading to high intracellular concentrations of substances and toxicants through reabsorptive and secretive processes; protein binding; large biotransformation 
capacity; and high oxygen consumption/delivery ratio in the outer medulla, leading to baseline medullary hypoxia and kidney injury [12, 14]. Nephrotoxins are thought to cause approximately $25 \%$ of all cases of acute and chronic renal failure [15].

The occupations and environmental solvents with known nephrotoxic potential include furniture making, dry cleaning, automotive manufacturing and repair, industrial cleaning, theatre routines, painting, varnish, and glue, as well as petroleum product retailing [16, 17]. Environmental toxins with known nephrotoxic potential include lead, cadmium, mercury, uranium, carbon tetrachloride, arsenic, and hydrocarbons [18]. Common sources of hydrocarbons include products such as gasoline, turpentine, furniture polish, household cleansers, propellants, kerosene, and other fuels.

In Nigeria, exposure to hydrocarbons is one of the main etiological factors contributing to the rising incidence of kidney disease, and many workers $(>10 \%)$ are continuously exposed to hydrocarbons, especially petrochemical and gasoline station workers [19]. It is estimated that about 110 million people globally are exposed to gasoline constituents for a few minutes per week and approximately 100 minutes per year while refueling at self-service gasoline stations $[20,21]$. It is also posited that service station workers are exposed to gasoline inhalation for many hours per week and approximately 8086 minutes per year. Interestingly, some gasoline compounds are nephrotoxic even at low concentrations [22]. The rising number of people exposed to gasoline compounds for various reasons, including industrial and domestic purposes, may explain the increasing nephrotoxicity.

Current exposure to risk factors eventually leads to future disease and a public health burden. However, knowledge of risk factors can be used to shift the population distribution [23]. Studies evaluating the histopathological features of gasoline-induced renal injury in humans are difficult; therefore, this toxicological study was carried out to assess the effect of GV on the biochemical and histomorphology of the kidney in rats.

\section{Materials and Methods}

Twenty-four matured, healthy Wistar albino rats weighing 180-200 g were obtained from the animal house at the Faculty of Basic Medical Sciences, University of Uyo, Nigeria. They were randomly divided into two groups ( $n=12$ per group): rats in group 1 (G1) served as the unexposed control group, while rats in group 2 (test group) were exposed to GV.

All animals were well acclimatized, housed in ventilated wooden cages with wood shavings as their bedding. Adequate ventilation, ambient temperature $\left(27 \pm 2^{\circ} \mathrm{C}\right), 44 \%$ relative humidity, and a $12-\mathrm{h}$ light-dark cycle were ensured throughout the study period. The animals were fed normal animal chow and allowed free access to water.

The research protocols were approved by the Institutional Animal Care and Use Committee and performed following the rules governing the internationally acceptable use of laboratory animals. Only animals in G2 were exposed to unleaded GV from gasoline purchased from a Nigerian National Petroleum Cooperation (NNPC) refueling station on Itam Ikot Ekpene Road in Uyo, Nigeria. The cages of the exposed animals were placed in exposure chambers ( 80 $\times 60 \times 100 \mathrm{~cm}$ ) containing two calibrated $500-\mathrm{mL}$ beakers containing petrol. The exposure duration was $6 \mathrm{~h}$ (9 am-3 pm) daily for 35 consecutive days. Differences in volume at the onset and end of the exposure period were calculated and were used to estimate the daily GV exposure. The average exposure was approximately $80 \mathrm{ml} /$ day.

At the end of the exposure period (35 days), the animals were sacrificed by chloroform anesthesia. Blood samples were collected by cardiac puncture, and the kidneys were removed, weighed, and fixed with $10 \%$ buffered formalin for tissue processing and histological examination.

Serum indices of renal function, including serum urea (Ur) and uric acid (UA), were determined using a multi-channel automated analyzer (SYNCHRON, Los Angeles, CA, USA). Serum electrolyte sodium $\left(\mathrm{Na}^{+}\right)$, potassium $\left(\mathrm{K}^{+}\right)$, chloride $\left(\mathrm{Cl}^{-}\right)$, bicarbonate $(\mathrm{HCO} 3)$, were determined with a flame photometer using lithium as an internal standard, and serum glucose (Glu) was determined using a multichannel automated measuring system (Lipid pro-TM, Model KM-001A; Infopia Co., Ltd., South Korea). Serum creatinine (Cr) levels were determined by Jaffe's method using $0.75 \mathrm{NaOH}$ and $1 \%$ picric acid (Sigma, St. Louis, MO, USA), which were added at a volume of $1 \mathrm{~mL}$ to each serum sample. After $15 \mathrm{~min}$ at room temperature, color changes (at $520 \mathrm{~nm}$ ) were measured spectrophotometrically (ESA, Inc., Chelmsford, MA, USA). Serum $\mathrm{HCO}^{-}$and $\mathrm{Cl}^{-}$were measured using standard methods.

\section{Statistical Analysis}

Data obtained were analyzed using descriptive statistics and reported as the mean \pm standard deviation (SD). Analysis of variance (ANOVA) was used. Differences in means between groups were examined using the independent t-test. Differences were considered statistically significant at $\mathrm{p}<0.05$. The analysis was performed using the Statistical Package for Social Sciences (SPSS) version 20.

\section{Results}

Serum biochemical markers of renal function in the exposed group differed significantly $(\mathrm{p}<0.05)$ from the unexposed group in urea $(45.16 \pm 1.00 \mathrm{mg} / \mathrm{dl}$ versus (vs) $13.20 \pm 0.69 \mathrm{mg} / \mathrm{dl})$, creatinine $(1.16 \pm 0.27 \mathrm{mg} / \mathrm{dl}$ vs $0.38 \pm 0.10 \mathrm{mg} / \mathrm{dl})$, uric acid $(3.66 \pm$ $0.82 \mathrm{mmol} / \mathrm{L}$ vs $1.96 \pm 0.08 \mathrm{mmol} / \mathrm{L})$, potassium $(6.90 \pm$ $0.27 \mathrm{mmol} / \mathrm{L}$ vs $3.57 \pm 0.26 \mathrm{mmol} / \mathrm{L})$, sodium $(182.60 \pm 3.21 \mathrm{mmol} / \mathrm{L}$ vs $141.33 \pm 10.46 \mathrm{mmol} / \mathrm{L})$, chloride $(119.00 \pm 1.58 \mathrm{mmol} / \mathrm{L}$ vs $103.33 \pm 2.07 \mathrm{mmol} / \mathrm{L}), \mathrm{pH}(6.82 \pm 0.22 \mathrm{vs} 7.38 \pm 0.25)$, bicarbonate $(16.60 \pm 5.03 \mathrm{mmol} / \mathrm{L}$ vs $26.50 \pm 3.45 \mathrm{mmol} / \mathrm{L})$, and glucose $(125.60 \pm 16.23 \mathrm{mg} / \mathrm{dl}$ vs $83.33 \pm 4.46 \mathrm{mg} / \mathrm{dl})$ (Figure 1).

Figure 2 shows that haematological indices significantly $(p<0.05)$ decreased in the exposed compared with unexposed group in packed cell volume $(21.15 \pm 1.06 \%$ vs $40.75 \pm 6.89 \%)$, haemoglobin concentration $(10.90 \pm 0.99 \mathrm{mg} / \mathrm{dl}$ vs $13.82 \pm 0.58 \mathrm{mg} / \mathrm{dl})$, total red blood cell counts $(6.40 \pm 0.28 \mathrm{~mm} 3$ vs $7.33 \pm 0.42 \mathrm{~mm} 3)$, mean cell haemoglobin $(15.00 \pm 1.41 \mathrm{pg}$ vs $17.83 \pm 1.47 \mathrm{pg})$, and mean cell 
haemoglobin concentration $(30.40 \pm 12.44 \mathrm{~mm} 3$ vs $33.47 \pm 2.04 \mathrm{~mm} 3)$ and significantly increased $(\mathrm{p}<0.05)$ in total white blood cell counts $(12.75 \pm 1.77 \mathrm{~mm} 3$ vs $3.13 \pm 1.11 \mathrm{~mm} 3)$.

Mean body weight $(120 \pm 15.02 \mathrm{~g}$ vs $123 \pm 10.75 \mathrm{~g})$, kidney weight $(1.62 \pm 0.37 \mathrm{~g}$ vs $1.82 \pm 0.51 \mathrm{~g})$, and ratio of body to kidney weight $(74.07 \pm 13.58$ vs $66.49 \pm 15.22)$ were not significantly different in the exposed compared with unexposed group $(p>0.05)$. MDA significantly $(\mathrm{p}<0.05)$ increased in the exposed $(11.10 \pm 0.41 \mathrm{mmol} / \mathrm{L}$ vs $5.81 \pm 0.55 \mathrm{mmol} / \mathrm{L}$ ) compared with unexposed group (Figure 3 ).

Figures 4 and 5 show the histopathological features of kidney sections from animals in the unexposed (G1) and exposed (G2) groups, respectively. Figure 4 (G1) shows normal kidney histomorphology, while Figure 5 (G2) shows areas of vascular degeneration (VD), cellular degeneration (CD), tubular necrosis (TN), and tubular degeneration, evidence of severe nephrotoxicity.

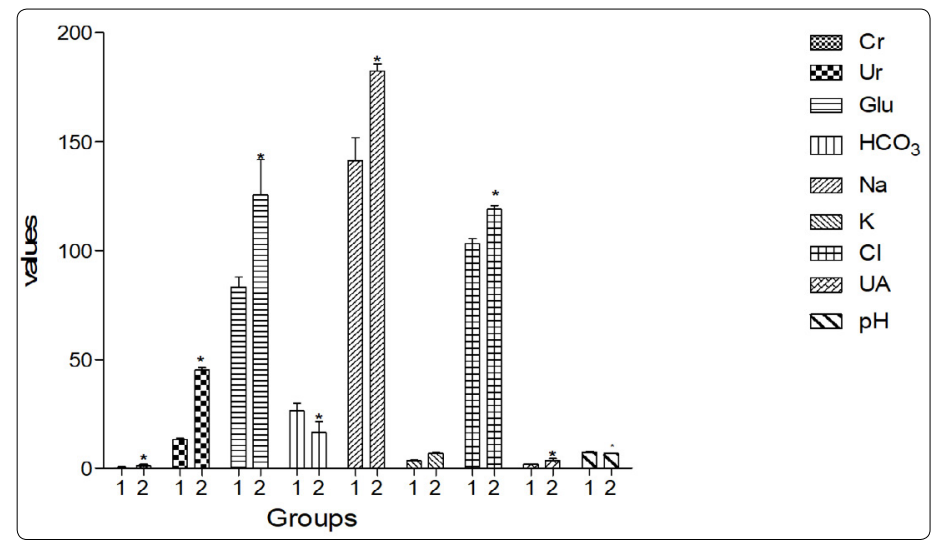

Figure 1: Figure 1 shows that the exposure of the experimental animals to $\mathrm{GV}$ was associated with a significant $(\mathrm{P}<0.05)$ increase in serum levels of $\mathrm{Cr}, \mathrm{Ur}, \mathrm{Glu}, \mathrm{Na}+, \mathrm{K}+, \mathrm{Cl}-$, and $\mathrm{UA}$, and a significant decrease in serum $\mathrm{pH}$ and bicarbonate level.

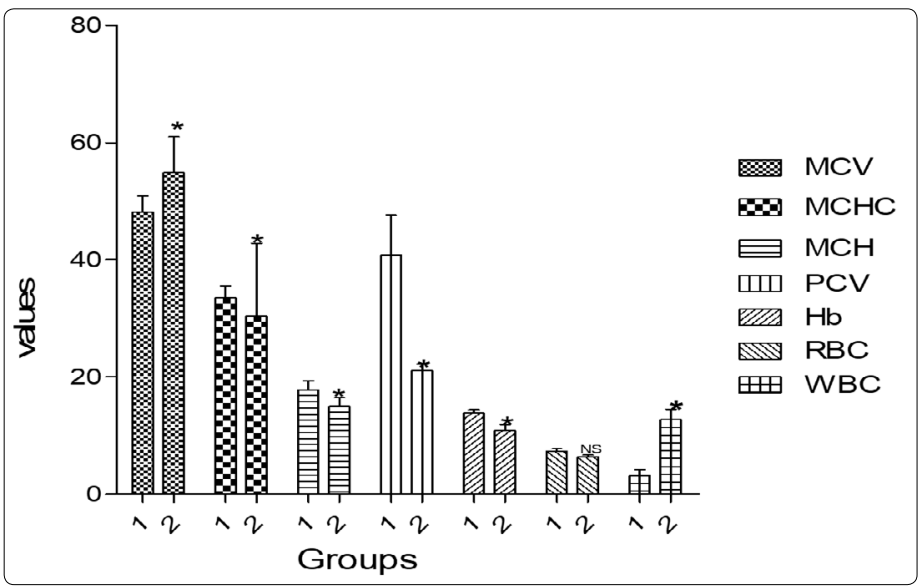

Figure 2: Figure 2 shows that animals exposed to $\mathrm{GV}$ had a significant $(\mathrm{p}<0.05)$ decrease in packed cell volume $(\mathrm{PCV})$, hemoglobin concentration $(\mathrm{HB})$, total red blood cell counts $(\mathrm{RBC})$, and mean cell hemoglobin $(\mathrm{MCH})$ and a significant $(\mathrm{p}<0.05)$ increase in total white blood cell count and mean cell hemoglobin concentration compared with animals in the control group
Figure 2 shows that animals exposed to $\mathrm{GV}$ had a significant $(p<$ 0.05) decrease in packed cell volume (PCV), hemoglobin concentration (HB), total red blood cell counts (RBC), and mean cell hemoglobin $(\mathrm{MCH})$ and a significant $(p<0.05)$ increase in total white blood cell count and mean cell hemoglobin concentration compared with animals in the control group.

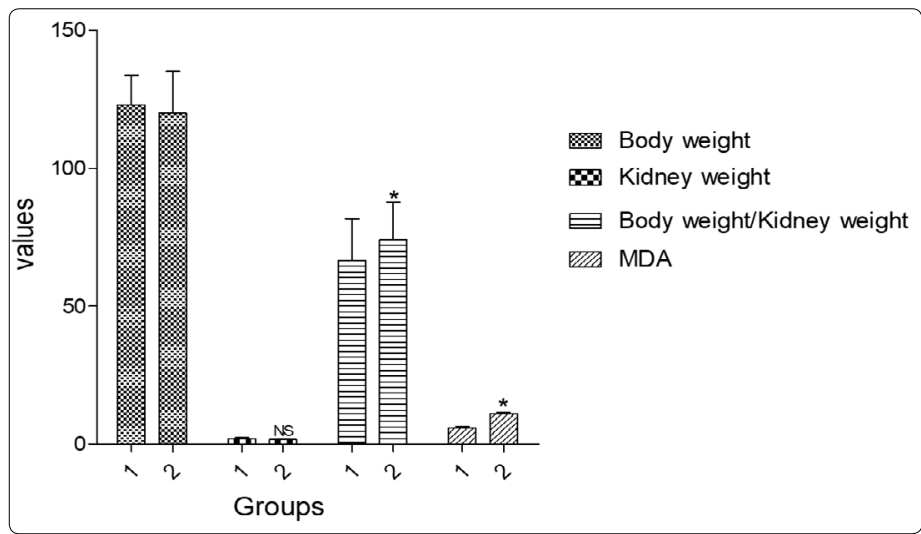

Figure 3: Mean body weight, kidney weight, and the ratio of body to kidney weight in the GV exposed group were not significantly different from those of the control group. MDA significantly $(\mathrm{p}<$ 0.05 ) increased in the exposed compared with the unexposed group.
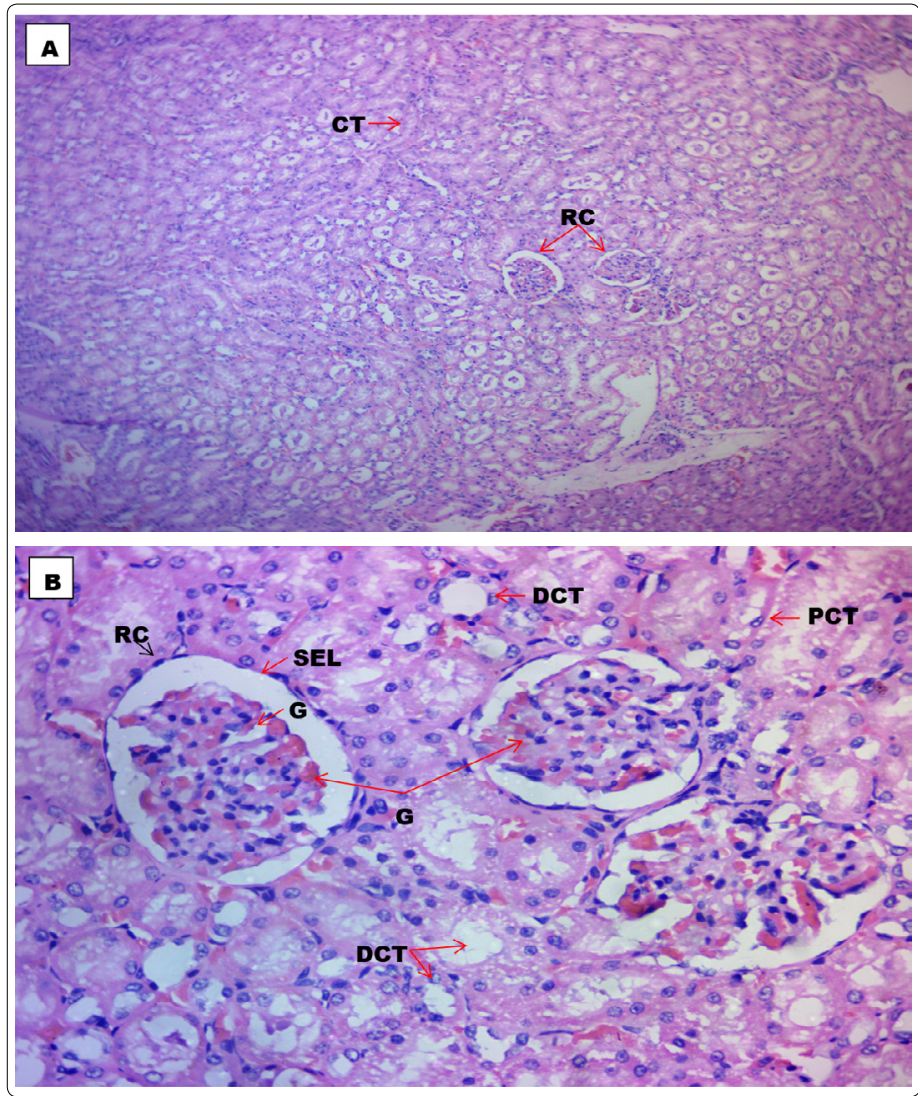

Figure 4 (G1): Shows the histological section of the kidney of animals in the control group at a magnification of A (x100), and $\mathrm{B}$ (x400) showing normal kidney morphology. $\mathrm{CT}=\mathrm{Convulated}$ Tubules, DCT=Distal Convoluted Tubule, $\mathrm{G}=$ Glomerulus, $\mathrm{PCT}=$ Proximal Convoluted Tubule, $\mathrm{RC}=$ Renal Corpuscle. 

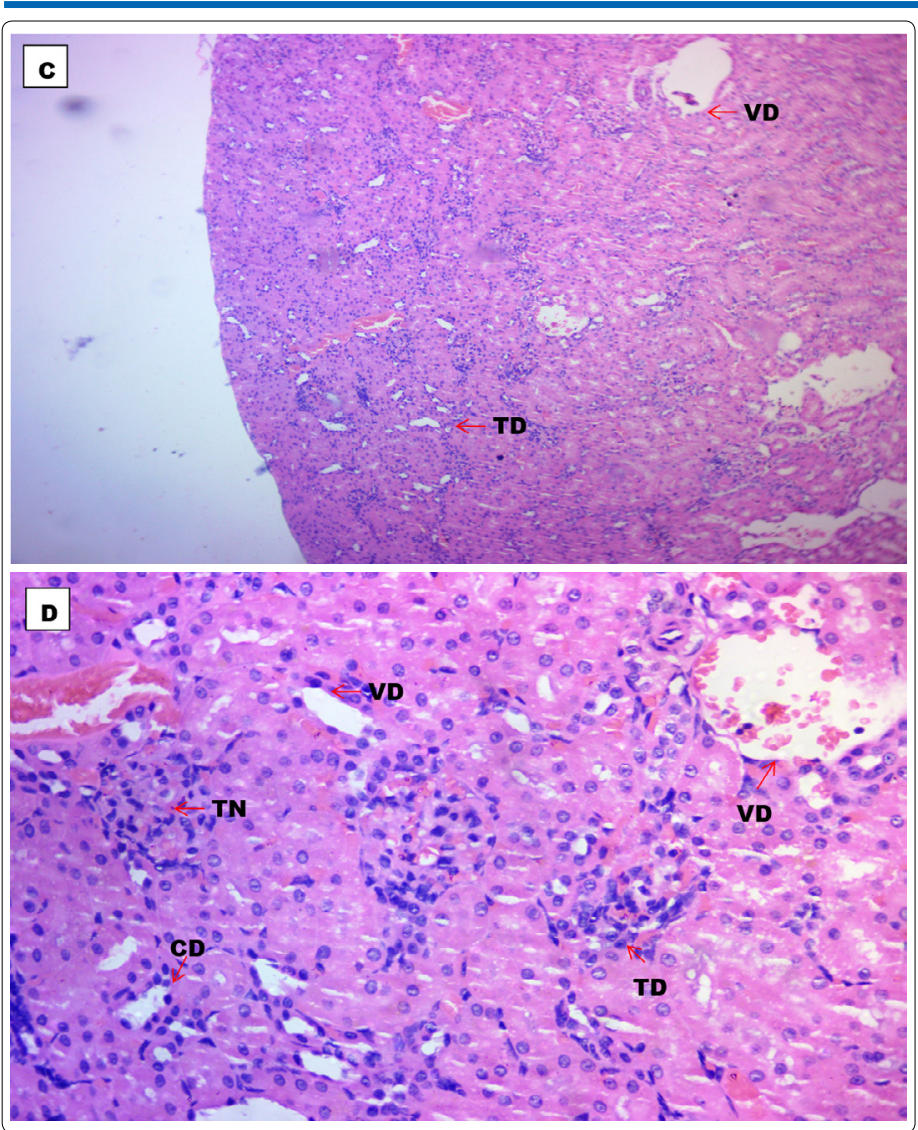

Figure 5 (G2): Shows the histological section of the kidney of animals exposed to $\mathrm{GV}(80 \mathrm{ml} /$ day $)$ for 35 days at magnification $\mathrm{C}(\mathrm{x} 100)$ and $\mathrm{D}(\mathrm{x} 400)$ showing areas of cellular degeneration (CD), Tubular degeneration (TD), Tubular necrosis (TN), and Vascular degeneration (VD)

\section{Discussion}

The results of this study showed a significant increase in serum levels of creatinine, urea, uric acid, electrolytes $\left(\mathrm{K}^{+}, \mathrm{Na}^{+}\right.$, and $\left.\mathrm{Cl}^{-}\right)$, glucose, and malondialdehyde (MDA), and decrease in bicarbonate $\left(\mathrm{HCO}^{-}\right)$and $\mathrm{pH}$ levels in gasoline-exposed compared with unexposed rats. Collectively, these findings are suggestive of oxidative stress-mediated renal disorders.

This notion is consistent with previous studies which showed that exposure to GV is associated with the induction of OS [22, 24, 25]. MDA is an end product of lipid peroxidation, a pathogenic step in OS-induced tissue damage. It has been used as a marker of increased OS associated with renal disease [26]. Therefore, a significant increase in serum MDA in exposed animals in the present study suggests the changes were OS-mediated [27].

OS is associated with damage to the renal structure and disruption of functional integrity, including damage to the membrane lipid bilayer (lipid peroxidation) and proteins, covalent binding to macromolecules, and alteration of the normal structure and function of cells, tissues, organs, and systems [25, 28].
GV-induced OS can disrupt the immune system, leading to immune perturbation and induction of autoimmune reactions causing accumulation of immune complexes in the kidney and kidney tissue damage [29]. Besides OS, gasoline (the parent nephrotoxicant) can also bind to the membrane lipid bilayer and proteins owing to its high lipophilicity, causing damage to both and leading to direct dose-dependent cytotoxicity [30]. There are associated disturbances of various cellular activities, including inhibition of sodium/potassium-adenosine triphosphatase $\left(\mathrm{Na}^{+} /\right.$ $\mathrm{K}^{+}$-ATPase) activity and several other enzymes involved in ionic and acid-base homeostasis. Indeed, exposure to GV carries a significant risk of electrolyte abnormalities and acid-base disturbances, as found in the present study.

Alternatively, gasoline can be biotransformed into reactive metabolites, such as 1,2,3-benzenetriol and benzoquinone, which bind covalently to macromolecules and in turn alter the activities of enzymes involved in homeostatic mechanisms (e.g., inhibition of $\mathrm{Na}^{+} / \mathrm{K}^{+}$-ATPase), resulting in cell injury. $\mathrm{Na}^{+} / \mathrm{K}^{+}$-ATPase plays a crucial role in the regulation of $\mathrm{Na}^{+}$reabsorption in the proximal tubule, establishing the electrochemical gradient needed to drive transepithelial transport of cations.

The $\mathrm{Na}^{+}-\mathrm{K}^{+}$ATPase pumps three $\mathrm{Na}^{+}$from the cell for every two $\mathrm{K}^{+}$pumped in, thereby acting like a three ion co-transport system for $\mathrm{Na}^{+}, \mathrm{K}^{+}$, and $\mathrm{Cl}^{-}$. When this enzyme is inhibited by gasoline constituent metabolites, its function is impaired, leading to an altered electrolyte, water, and acid-base homeostasis as well as structural abnormalities in renal cells and tissues, as were observed in the present study. Therefore, gasoline toxicity can lead to diverse forms of electrolyte disturbances, including hypernatraemia, hyperchloraemia, hypokalaemia, and metabolic acidosis due to distal renal tubular acidosis. This explains in part the significant increase in serum electrolytes $\left(\mathrm{K}^{+}, \mathrm{Na}^{+}\right.$, and $\left.\mathrm{Cl}^{-}\right)$and decreases in $\mathrm{pH}$ and $\mathrm{HCO}^{-}$levels observed in the present study. Similarly, the decrease in serum $\mathrm{pH}$ (increased $\mathrm{H}^{+}$concentration) and the concomitant decrease in $\mathrm{HCO}^{-}$suggest the presence of GV-induced metabolic acidosis due to impaired renal acid-base homeostatic mechanisms.

Empirical evidence indicates that a significant decrease in serum $\mathrm{HCO}^{-}$, as was observed in the present study, may indicate a renal response to excess $\mathrm{H}^{+}$concentration (acidosis) in the body. It is known that in acidosis, the kidney does not excrete HCO3- into the urine, instead, it is reabsorbed, and new bicarbonate is produced, which is added back to the extracellular fluid (ECF). This reduces the ECF $\mathrm{H}^{+}$concentration towards normal levels. Thus, the kidney regulates the $\mathrm{ECF} \mathrm{H}^{+}$concentration through three basic mechanisms, secretion of $\mathrm{H}^{+}$, reabsorption of filtered $\mathrm{HCO} 3$ , and production of new $\mathrm{HCO}^{-}$.

These mechanisms occur in virtually all parts of the tubules, except the descending and ascending thin limbs of the loop of Henle. This provides a plausible reason for the significant decrease in serum HCO3- observed in the present study. Furthermore, the kidney is a major organ for the excretion of metabolic waste, and 
a significant increase in the levels of serum $\mathrm{Cr}$, $\mathrm{Ur}$, UA, and electrolytes may indicate impairment of the excretory and concentration functions of the kidney, which are responsible for maintenance of a constant extracellular environment by excreting and regulating water and electrolyte balance. This idea is supported by previous studies with similar findings [22, 31].

The histopathological changes in renal tissue observed in animals exposed to gasoline in the present study provide ancillary evidence for the changes in the biochemical markers of nephrotoxicity. Specifically, the structural changes observed include tubular degeneration and necrosis and vascular and cellular degenerative changes. Greater damage to the renal tubules was also observed, especially the proximal tubules, which showed evidence of tubular degeneration and necrosis.

These observations are consistent with previous studies that reported the high vulnerability of the proximal tubules to nephrotoxins $[30,32]$. It has been shown that this segment of the nephron receives a large number of solutes filtered at the glomerulus, and because this compartment is rich in inducibletype mixed-function oxidases, including cytochrome P450 (CYP450) enzyme, it can metabolize gasoline compounds and convert them into toxic reactive metabolites that can damage glomerular and tubular cells [32]. Other postulated mechanisms underlying gasoline compound-mediated kidney damage include $\beta$-lyase-mediated bioactivation of halogenated hydrocarbons [12]. The alpha $2 \mu$ globulin-mediated pathway that leads to nephropathy in male rats has also been implicated [12]. Besides the direct nephrotoxic effects of gasoline compounds, derangement of other biochemical indices, including hematological, hormone, and lipid sub-fraction, which can secondarily affect kidney function and vice versa, were also observed in the present study. For example, excess circulating haem caused by solvent-induced rhabdomyolysis or hemolysis of red blood cells has been posited to cause acute tubular necrosis [12]. In addition, the presence of metabolic acidosis in the GV-exposed animals could have secondarily contributed to the decline in renal function through stimulation of adaptive mechanism aimed at restoring acid-base homeostasis. These mechanisms are detrimental to renal endpoints and include the production of ammonia (ammonia genesis) and the subsequent generation of new bicarbonate [33]. It has been shown that ammoniogenesis leads to activation of the third component of complement (C3) through an alternative pathway, and subsequent reaction of ammonia with $\mathrm{C} 3$ triggers the alternative complement pathway, leading to progressive kidney damage. Similarly, the production of new bicarbonate in the kidney alkalinizes the interstitium, resulting in calcium $\left(\mathrm{Ca}^{+}\right)$precipitation and causing kidney damage [34]. Furthermore, there is increased renal endothelin-1 activity and activation of the renin-angiotensin system (RAS). Increase RAS activity leads to increased aldosterone production. Excess aldosterone production leads to hemodynamic changes, a reduced glomerular filtration rate (GFR), and by extension, a decline in other renal functions.
In conclusion, chronic exposure to GV may be associated with histopathological and biochemical nephrotoxic changes. The present results highlight the need for safety measures against GV exposure through medical surveillance, early detection, and intervention to minimize GV exposure and manage suspected cases of exposure.

\section{Acknowledgments}

The authors acknowledge the numerous contributions made by Mr. Samson Kayode, Mrs. Nyebuk Daniel, and the Staff of the Department of Physiology, University of Uyo, Nigeria, particularly the laboratory technologists for their professional advice.

\section{References}

1. Ulasi I, Ijoma CK, Onodugo OD, Arodiwe EB, Ifebunandu NA, et al. (2013) Towards prevention of chronic kidney disease in Nigeria: a community-based study in Southeast Nigeria. Kidney International Supplements 3: 195-201.

2. Samak MJ, Levey AS, Schoowertho AC, Coresh J, Culleton B, et al. (2003) Kidney disease as a risk factor for the development of cardiovascular disease. A statement from the American Heart Association Councils on kidney in cardiovascular disease, High blood pressure research, clinical cardiology, and epidemiology and prevention. Circulation 108: 2154-2169.

3. Borssan IB (2007) Recommendations for early diagnosis of chronic kidney disease. Annals of African Medicine 6: 130-136.

4. Mabayoje MO, Bamgboye EL, Odutola TA, Mabadeje AF (1992) Chronic renal failure at a 10 -year review. Transplant Proc 24: 1851-1852.

5. Abioye EA, Akinsola A, Ezeoma I (1995) Renal disease: the need for community-based screening in rural Nigeria. Afr $\mathrm{J}$ Med Pract 6: 198-201.

6. Nwankwo E, Bello AK, Elnahas AM (2005) Chronic kidney disease; stemming the global tide. American Journal of Kidney Disease 45: 201-208.

7. Alebiosuco, Ayodele LY (2005). The global burden of chronic kidney disease and the way forward. Ethn Dis 15: 520-521.

8. Okoye OC, Oviasu E, Ojogwu L (2011) Prevalence of chronic kidney disease and its risk factors amongst adults in a rural population in Edo state, Nigeria. Journal of US China Medical Science 8: 471-481.

9. Feehally J (2005) Ethnicity and renal disease. Kid Int 6: 414424.

10. Norris KC, Agodoa LY (2005). Unraveling the racial disparities associated with kidney disease. Kid Int 68: 914-924.

11. Prasher D, Morata T, Campo P, Fechter L, Johnson AC, et al. (20020. Noise chem: a European Commission research project on the effects of exposure to noise and industrial chemicals on hearing and balance. International Journal of Occupational Medicine and Environmental Health 15: 5-11. 
12. Voss JU, Roller M, Mangelsdorf I (2003) Nephrotoxicity of organic solvents. A literature survey. Federal Institute for Occupational Safety and Health. Friedrich-Henkel-Weg. Dertmund Germany 1-25: 44149.

13. Papadopoulos G, Paraskevi G, Papazoglou C, Michalion (2010) Occupational and public health and safety in a changing work environment: An integrated approach for risk assessment and prevention. Safety Science 48: 943-949.

14. Bovee KC (1986) Renal function and laboratory evaluation. Toxicological Pathology 14: 26.

15. Bahner U, Heidland A (1998) Acetylsalicylic acid in renal insufficiency. INTERNIST 39: 1186-1186

16. Meon BE, Hollund BE, Riise T (2008). Neurological Symptoms among dental assistants: a cross-sectional study. Journal of Occupational Medicine and Toxicolology 3: 1000.

17. Kamen Bouhadiba F, Gana N, Aoued A, Tebboune B (2010) Neurobehavioral Testing in Worker Occupationally exposed to Solvents in the Manufacturing of Paints, Glues, and Vanishes in Oran. J Int Sanxe Trav 2: 40-46.

18. Wedeen RP (1997) Occupational and environmental renal disease. Semin Nephrol 17: 46-53.

19. Awodele O, Salayman AA, Akintonwa A (2014) Evaluation of hematological, hepatic, and renal function of petroleum tanker drivers in Lagos, Nigeria. African Health Science 14: 178-184.

20. Caprino L, Togno GI (1998) Potential health effects of gasoline and its constituents; a review of current literature (1990-1997) on toxicological data. Environ. Health Perspect 106: $115-125$.

21. Wixtrom RN, Brown SL (1992). Individual and population exposures to gasoline. J Expo Anal Environ Epidemiol 2: 23-78.

22. El-shaker AA, El-Ebiarie AS, Ibrahim YH, Abdel MAE, ElMekawy AM, et al. (2015) Effect of benzene on oxidative stress and the function of liver and kidney in rats. Journal of Environmental and Occupational Science 4: 34-39.

23. Ekpenyong CE, Udoinyang CI (2014) Associations between worker characteristics, workplace factors, and work-related musculoskeletal disorders: A cross-sectional study of male construction workers in Nigeria. International Journal of Occupational Safety and Ergonomics 20: 447-462.
24. Small DM, Coombes JS, Bennett N, Johnson DW, Gobe GC, et al. (2012) Oxidative stress, anti-oxidant therapies, and chronic kidney disease. Nephrology 17: 311-321.

25. Azeez OM, Akhigbe RE, Anigbogu CN (2013) Oxidative status in rat kidney exposed to petroleum hydrocarbons. J Nat Sci Med 4: 149-154.

26. Atamer A, Kocyight Y, Ecder SA (2008) Effect of oxidative stress on antioxidant enzyme activities, homocysteine, and lipoproteins in chronic kidney disease. Journal Nephrology 21: 924-930.

27. Johnson DW, Armstrong K, Campell SB, David W Mudge, Carmel M Hawleye, et al. (2007). Metabolic syndrome in severe chronic kidney disease: prevalence, predictors, prognostic significance, and effects of risk factor modification. Nephrology 12: 391-398.

28. Roberts JM, Hubel CA (2004) Oxidative stress, preeclampsia. American Journal of Obstetric Gynecology 190: 11.

29. Weening JJ (1989) Mechanisms leading to toxin-induced impairment of renal function with a focus on immunology. Toxicol Lett 46: 205-211.

30. Jakubowski M (2005) Influence of occupational exposure to organic solvents on kidney function. International Journal of Occupational Medicine and Environmental Health 18: 5-14.

31. Jia C, Batterman S, Godwin C (2008) VOCs in industrial, urban, and suburban neighborhoods. Part 1: indoor and outdoor concentrations, variation, and risk drivers. Atmos Environ 42: 2083-100.

32. Bulger RE (1986) Morphology of the kidney: update 1985. Toxicologic Pathology 14: 13-25.

33. Nath KA, Hostetter TH (1985) Pathophysiology of chronic tubule interstitial disease in rats. Interactions of dietary acid load, ammonia, and complement component C3. J Clin Invest 76: 667-675.

34. Ekpenyong CE, Daniel NE, Antai AB (2012) Double Burden, Non-Communicable Diseases, and Risk Factors Evaluation in Sub-Saharan Africa: The Nigerian Experience. European Journal of Sustainable Development 1: 249-270.

Copyright: (12020 Christopher Edet Ekpenyong, et al. This is an open-access article distributed under the terms of the Creative Commons Attribution License, which permits unrestricted use, distribution, and reproduction in any medium, provided the original author and source are credited. 